\title{
WHAT MUST REMAIN
}

\author{
A heroic effort.
}

BY THOMAS BRODERICK

$\mathrm{T}$ he bonfire wouldn't light.

The man cursed under his breath. It was already after sunset, and he didn't have enough time to get more starter from his cabin. After waiting for the late spring breeze to calm, he lit his final match. Thankfully, the fire took, and in less than a minute, the five-foot stack of birch logs was burning well. Pulling at his short grey beard, the man grinned. He wore a pristine military uniform adorned with polished medals and ribbons. Around him, the firelight illuminated smooth aluminium and glass, but not enough to tell what was hiding in the darkness.

As twilight disappeared from the sky, a school bus arrived at the museum's gate. The driver followed the reflectors the man had set up earlier in the day. It would be a shame to run into one of the many outdoor exhibits.

When the bus stopped near the fire, the man boarded it and addressed the group of nine-year-olds and their young teacher. "Welcome to Roninom. My name is Major Gerard Rovego. I flew for the Imperial Space Force in the last war. I now look after our country's greatest spaceships so that children like you have the opportunity to learn about and appreciate them." The man had been the museum's caretaker for nearly a decade.

The man led the students to the fire, where there were folding chairs for everyone. The teacher distributed juice boxes and cookies, a rare treat.

The children had so many questions. "What was it like flying in space?"

"An amazing experience! You feel like a bird soaring through the heavens." The man had never flown in space, nor ever left the ground for that matter.

"Do the spaceships here still work?"

"Of course! Why would our great country put them on display if they didn't?" The spaceships were little more than shells.

After a few more questions, the children began to yawn. "Is it time for the Miraz?" a boy asked, his eyes half-closed. The other children grinned widely. They had heard

ONATURE.COM Follow Futures:

\section{\% @NatureFutures}

f go.nature.com/mtoodm the stories from the older students at their school.

The walk to the Miraz took only a

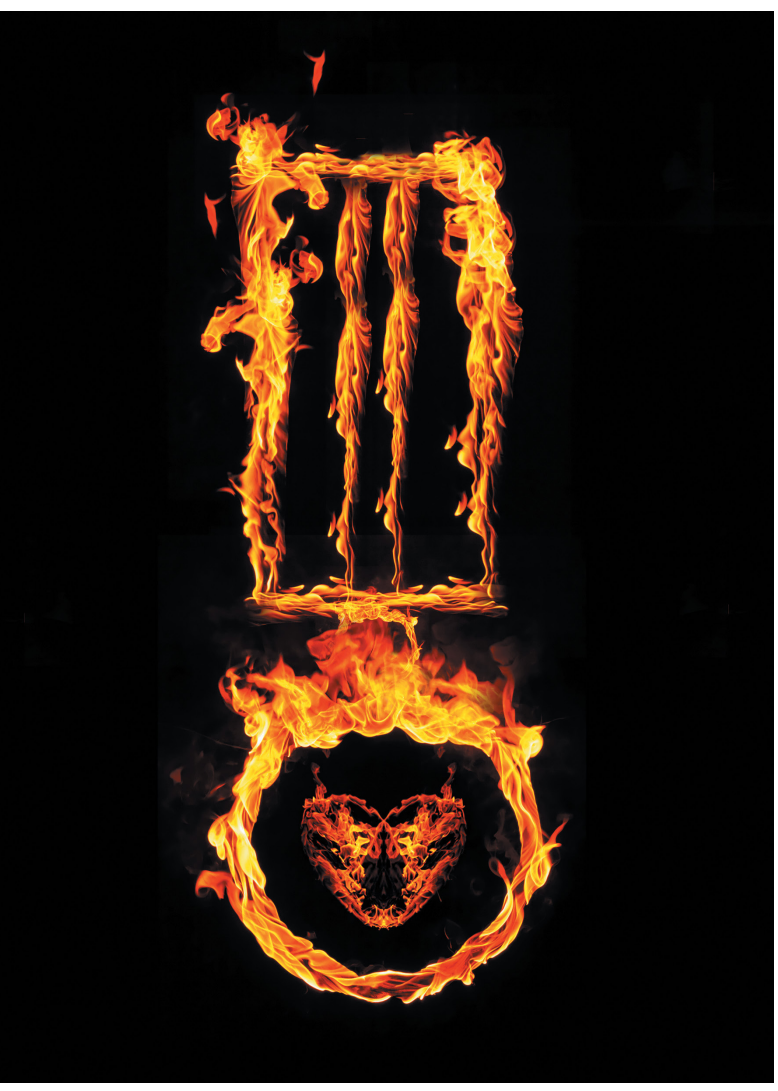

"What's making all the light in here?" A boy asked.

"The Miraz's mighty fusion engine! Just a pea-sized amount of fuel can power the Miraz for a century." The man had daisy-chained a few car batteries to the ship's electrical system.

The man walked down the centre aisle. "Get some rest. Tomorrow I'll show you all the beautiful spaceships I have here." The spaceships were the last examples of the once mighty Imperial Space Force.

"Can we go inside them, too?" It was the boy in the very last row.

The man put his hand on the boy's shoulder and looked him in the eyes. "As many as you want." That was true, but only for the spaceships that he had spent his meagre pension restoring.

A girl tugged on the man's trousers. He turned to her.

"Major Rovego." She paused to swallow. "Were you scared in the war?"

The man smiled at the girl. "Never. I knew I'd come home one day." Major Gerard Rovego was killed in action while piloting the Miraz's sister ship, the Realnos.

The children asleep, the teacher

few seconds. Fifteen feet above them, the dark oval ship waited. Its four claw feet dug into the tall grass. The children gasped as the hatch silently slid open and a staircase descended to the ground.

At the top of the steps, each child received a personalized ticket along with a pillow and blanket. They were wide-eyed with wonder as they found their sleeping berths in the roomy cabin. "This is softer than my bed at home," one girl said after lying down.

"After I graduated flight school," the man began once all the children were tucked in, "I piloted ships like the Miraz. Passengers slept in these very berths as they travelled to the Moon. And the Miraz was so fast. You'd fall asleep on Earth and wake up on the lunar surface.

"I was such a dedicated pilot that the Empire promoted me to major." The Empire pressed all civilian pilots into military service in the war's final stages.

"Did this ship really go to the Moon?" A girl asked.

"Hundreds of times." The Miraz had never flown, and the few ships that had were retrofitted as bombers in a last-ditch effort to stave off defeat. took the man aside. "Thank you so, so much," she whispered. "The children will remember this for the rest of their lives. Not the stories of the defeat, not the horror of what their grandparents did, but this. The country must have its heroes, and children should know them."

The man accepted the few bills the teacher gave him.

"You're welcome." He would use the money to restore more of the Miraz's interior.

The man returned to his cabin at the edge of the museum grounds. He carefully removed his brother's uniform. While ironing the trousers, he noticed the small wrinkle where the girl had grabbed them.

"You probably hate me, Gerard," the man whispered. "You'd say that children should learn the truth about the war. I know that if you ever saw this place, you ... you wouldn't stop at just a bonfire.

"But then I would have nothing left." $\mathrm{He}$ worried that his brother had died for nothing.

The man ironed out the wrinkle.

Thomas Broderick is a freelance writer living in Northern California. You can read more of his stories at broderickwriter.com. 